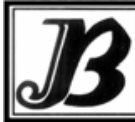

J. bio-sci. 16: 19-24, 2008

ISSN 1023-8654

http://www.banglajol.info/index.php/JBS/index

\title{
GROWTH ATTRIBUTES OF BARLEY (HORDEUM VULGARE L.) IN RELATION TO SOIL MOISTURE REGIMES AND NPK FERTILIZERS
}

\author{
M S I Mollah and N K Paul|* \\ Institute of Biological Sciences, University of Rajshahi, Rajshahi-6205, Bangladesh \\ ${ }^{1}$ Department of Botany, University of Rajshahi, Rajshahi-6205, Bangladesh
}

\begin{abstract}
An experiment was conducted in the experimental field of Rajshahi University Campus, Bangladesh during the rabi season of 2004-2005 to study the growth attributes of four varieties of barley (BARI Barley-1, BARI Barley-2, BHL-3, BL-1) in relation to different soil moisture regimes and NPK fertilizers. Three levels of irrigation $\left(l_{0}, l_{1}, I_{2}\right)$ and four levels of NPK fertilizers $\left(F_{0}, F_{1}, F_{2}, F_{3}\right)$ were adopted in split-split plot design with three replications. Total dry matter (TDM), leaf area index (LAI) and crop growth rate (CGR) were increased with increasing number of irrigations. Net assimilation rate (NAR) fluctuated but in most of the cases, it was highest and lowest in the $\mathrm{I}_{2}$ treatment at the first and last harvest. With few exceptions, $l_{0}$ treatment had the highest and lowest leaf area ratio (LAR) at the first and last harvest, respectively. The highest and lowest TDM, LAI and CGR were in the $F_{3}$ and $F_{0}$ treatment, respectively. NAR was higher in the fertilized plant than in the control plants. The highest and the lowest LAR were in the $F_{0}$ treatment at the first and last harvest, respectively. Most of the growth attributes were higher in BHL-3.
\end{abstract}

Key words: Barley, irrigation regimes, NPK fertilizers, growth attributes.

\section{Introduction}

Barley (Hordeum vulgare L.) is the fourth grain crop both in area and production in the world after maize, wheat and rice. In Bangladesh, it is grown as rabi crop and ranks third after rice and wheat as supplementary food and fodder crops (FAO 2002). It has the potential to become one of the important cereal crops in Bangladesh. Productivity of this crop is very poor compared to that of the other countries. Improved cultural practices such as proper land preparation, time of sowing, use of optimum doses of fertilizers and irrigation may raise the yield of this crop.

The present investigation was undertaken to assess optimum irrigation frequencies and to find out economic and optimum doses of N, P and $\mathrm{K}$ fertilizers as well as suitable variety of barley with respect to crop growth stages for ensuring better growth and higher yield.

\section{Materials and Methods}

The experiment was conducted in the experimental field of Rajshahi University Campus (Agro-ecological zone 11), Bangladesh during the period from November 2004 to March 2005. Four varieties of barley, BARI Barley-1, BARI Barley-2, BHL-3 and BL-1 were taken. The soil of the field was silty loam, having pH 7.5 and $35 \%$ of field capacity. The experiment was arranged in split-split design with three replications. Each replicated field was divided into three main plots for irrigation treatment. Each main plot was divided into four

\footnotetext{
${ }^{*}$ Corresponding author.
} 
sub-plots for fertilizer treatment. Each sub-plot was lastly into four sub-sub plots for four varieties of barley. Three levels of irrigation treatments were adopted, viz., rain fed $\left(l_{0}\right), 20 \mathrm{~mm}$ irrigation $\left(I_{1}\right)$ and $40 \mathrm{~mm}$ irrigation $\left(I_{2}\right)$ at every 30 days interval for three times during the growing period. Four levels of fertilizer treatments were used. NPK levels (kg/ha) for N as urea were $0,40,80$ and 120; for P as TSP were 0, 25, 50 and 75 and lastly for $K$ as MP were $0,15,30$ and 45 . These recommended basal doses of fertilizers were applied as $F_{0}$, $F_{1}, F_{2}$ and $F_{3}$ at each split plot before sowing. Each split plot size was $4.0 \mathrm{~m} \times 1.8 \mathrm{~m}$, i.e., $7.2 \mathrm{~m}^{2}$ having a plot to plot distance $1 \mathrm{~m}$ to the north-south, $2 \mathrm{~m}$ to the east-west; replication to replication distance was $2 \mathrm{~m}$, row to row $20 \mathrm{~cm}$ and plant to plant $5 \mathrm{~cm}$. Border rows were considered because of the border effect. Necessary inter-cultural operations such as weeding, expelling the birds and rats were adopted and no fungicides or insecticides were used. After seedling emergence, seedlings were thinned to uniform and desirable number of plants. For this, two weeding were done manually, one at 30 days after sowing (DAS) and the other at 60 DAS.

For growth analysis, plants were harvested at 10 days intervals and the first harvest was taken at 20 DAS. Using the spreadsheet analysis program Microsoft Excel Version 7.0, various growth attributes were calculated from leaf area and dry weight data. Statistical analysis was carried out according to Gomez and Gomez (1984).

\section{Results and Discussion}

Effect of irrigation: Total dry matter (TDM) was higher in the irrigated plants than in the rainfed plants (Table 1). I $I_{2}$ treatment had the highest TDM. Similar results were reported in wheat by Simane et al. (1993), Sarker et al. (1996), Sarker and Paul (1997), Nahar and Paul (1998) and Rahman et al. (2001). TDM increased slowly at the early stages of growth and then increased rapidly with the advancement of plant age. The cause of rapid increase of TDM at the later stages was possibly due to the development of a considerable number of late tillers. Similar result was reported in wheat by Talukder (1987) in wheat. Irrigated plants had higher LAl than the control plants (Table 1). Similar results were reported in wheat by Nahar and Paul (1998) and Siddique et al. (1999) and in barley by Kirby (1969). The highest LAI was produced by the highest irrigation ( $I_{2}$ treatment). Starting from a lower value, LAI reached in a certain value and then declined with plant age. The increase of LAl occurred due to the increase of leaf expansion in the irrigated plants. Increase in soil moisture resulted in increased turgor pressure in the cells and turgor forces played a part in the process of leaf expansion. Compared to the control, CGR was higher in the irrigated plants (Table 1). The highest CGR was in the plants grown under the highest $\mathrm{I}_{2}$ treatment of irrigation. CGR increased rapidly at the early growth stages and reached the highest value at 60-70 DAS and thereafter, it declined. Similar trend of the effect of irrigation was also observed by Sarker et al. (1996), Sarker and Paul (1998) and Nahar and Paul (1998). Lower NAR was in the irrigated plants than in the control. Decreased NAR due to irrigation was also noticed in wheat by Saha and Paul (1995), Sarker and Paul (1998) and Nahar and Paul (1998). NAR of $I_{0}$ and $I_{1}$ treatments declined very slowly from early higher value, increased again and finally reached its higher value. But NAR of $I_{2}$ treatment declined throughout the whole growing season. LAR at the initial stage was higher in the rainfed plants than in the irrigated plants and at later stage, it was reversed, i.e., the rainfed plants had higher LAR than the irrigated plants (Table 1). Similar results were reported by Nahar and Paul (1998) in wheat. LAR was maximum at 20 DAS and decreased steadily with increasing plant age. It might be

due to the abscission of mature and older leaves at the later growing stages. Similar results were reported in sugar beet, potato and barley by Thorne (1960) and in wheat by Saha and Paul (1995). 
Growth attributes of barley

Table 1. Mean values of TDM, LAI, CGR, NAR and LAR as affected by different irrigation regimes at different growth stages.

\begin{tabular}{|c|c|c|c|c|c|c|c|c|}
\hline \multicolumn{9}{|c|}{ Days after sowing } \\
\hline Irrigation & 20 & 30 & 40 & 50 & 60 & 70 & 80 & 90 \\
\hline \multicolumn{9}{|c|}{ TDM $\left(\mathrm{g} \mathrm{m}^{-2}\right)$} \\
\hline$I_{0}$ & 4.09 & 9.66 & 21.07 & 41.78 & 74.61 & 119.83 & 173.76 & 230.24 \\
\hline$l_{1}$ & 4.23 & 11.40 & 27.74 & 59.73 & 112.71 & 185.93 & 269.04 & 345.52 \\
\hline $\mathrm{I}_{2}$ & 4.38 & 14.06 & 38.48 & 88.84 & 172.20 & 279.69 & 380.63 & 435.25 \\
\hline \multicolumn{9}{|l|}{ LAI } \\
\hline $\mathrm{I}_{0}$ & 0.15 & 0.31 & 0.57 & 0.91 & 1.23 & 1.41 & 1.38 & 1.13 \\
\hline$l_{1}$ & 0.15 & 0.37 & 0.82 & 1.50 & 2.22 & 2.68 & 2.60 & 2.03 \\
\hline \multirow[t]{2}{*}{$\mathrm{I}_{2}$} & 0.15 & 0.50 & 1.15 & 2.32 & 3.64 & 4.40 & 4.08 & 2.91 \\
\hline & $20-30$ & $30-40$ & $40-50$ & $50-60$ & $60-70$ & $70-80$ & $80-90$ & \\
\hline \multicolumn{9}{|c|}{$\operatorname{CGR}\left(\mathrm{g} \mathrm{m}^{-2} \mathrm{day}^{-1}\right)$} \\
\hline $\mathrm{l}_{0}$ & 0.56 & 1.14 & 2.07 & 3.28 & 4.52 & 5.39 & 5.65 & \\
\hline$I_{1}$ & 0.72 & 1.64 & 3.20 & 5.30 & 7.32 & 8.31 & 7.65 & \\
\hline $\mathrm{I}_{2}$ & 0.97 & 2.44 & 5.04 & 8.34 & 10.75 & 10.10 & 5.46 & \\
\hline \multicolumn{9}{|c|}{ NAR $\left(\mathrm{g} \mathrm{cm}^{-2}\right.$ day $\left.^{-1}\right) \times 10^{-4}$} \\
\hline $\mathrm{l}_{0}$ & 1.93 & 1.90 & 1.95 & 2.18 & 2.55 & 3.35 & 4.93 & 8.68 \\
\hline$I_{1}$ & 2.33 & 2.08 & 2.00 & 2.08 & 2.40 & 3.13 & 4.73 & 8.33 \\
\hline $\mathrm{I}_{2}$ & 2.70 & 2.30 & 2.20 & 2.10 & 1.90 & 1.45 & 0.20 & -2.88 \\
\hline \multicolumn{9}{|c|}{$\operatorname{LAR}\left(\mathrm{cm}^{2} \mathrm{~g}^{-1}\right)$} \\
\hline$l_{0}$ & 368.90 & 327.09 & 272.17 & 212.95 & 157.03 & 109.44 & 72.27 & 45.35 \\
\hline$I_{1}$ & 350.67 & 329.12 & 288.45 & 236.12 & 180.54 & 128.90 & 85.90 & 53.41 \\
\hline $\mathrm{I}_{2}$ & 343.57 & 314.37 & 279.41 & 235.84 & 186.60 & 137.45 & 93.93 & 59.51 \\
\hline
\end{tabular}

Table 2. Influence of fertilizer on mean values of TDM, LAI, CGR, NAR and LAR at different growth stages.

\begin{tabular}{|c|c|c|c|c|c|c|c|c|}
\hline \multicolumn{9}{|c|}{ Days after sowing } \\
\hline Fertilizer & 20 & 30 & 40 & 50 & 60 & 70 & 80 & 90 \\
\hline \multicolumn{9}{|c|}{ TDM $\left(\mathrm{g} \mathrm{m}^{-2}\right)$} \\
\hline $\mathrm{F}_{0}$ & 3.20 & 6.16 & 11.78 & 21.92 & 39.15 & 67.01 & 110.76 & 179.90 \\
\hline $\mathrm{F}_{1}$ & 4.05 & 11.15 & 27.13 & 57.90 & 107.87 & 174.97 & 246.98 & 303.88 \\
\hline $\mathrm{F}_{2}$ & 4.45 & 13.53 & 34.83 & 77.08 & 145.84 & 235.32 & 323.76 & 380.86 \\
\hline $\mathrm{F}_{3}$ & 5.12 & 15.97 & 42.65 & $\begin{array}{l}96.90 \\
\mathrm{LAI}\end{array}$ & 186.50 & 303.25 & 416.40 & 483.48 \\
\hline $\mathrm{F}_{0}$ & 0.14 & 0.20 & 0.26 & 0.32 & 0.36 & 0.38 & 0.36 & 0.32 \\
\hline $\mathrm{F}_{1}$ & 0.14 & 0.36 & 0.84 & 1.52 & 2.25 & 2.67 & 2.54 & 1.95 \\
\hline $\mathrm{F}_{2}$ & 0.15 & 0.44 & 1.04 & 1.97 & 2.99 & 3.59 & 3.41 & 2.58 \\
\hline \multirow[t]{2}{*}{$\mathrm{F}_{3}$} & 0.16 & 0.50 & 1.25 & 2.48 & 3.87 & 4.69 & 4.42 & 3.25 \\
\hline & $20-30$ & $30-40$ & $40-50$ & $50-60$ & $60-70$ & $70-80$ & $80-90$ & \\
\hline \multicolumn{9}{|c|}{ CGR $\left(\mathrm{g} \mathrm{m}^{-2}\right.$ day $\left.^{-1}\right)$} \\
\hline $\mathrm{F}_{0}$ & 0.30 & 0.56 & 1.01 & 1.72 & 2.79 & 4.38 & 6.91 & \\
\hline$F_{1}$ & 0.71 & 1.60 & 3.08 & 5.00 & 6.71 & 7.20 & 5.69 & \\
\hline$F_{2}$ & 0.90 & 2.13 & 4.23 & 6.88 & 8.95 & 8.84 & 5.70 & \\
\hline $\mathrm{F}_{3}$ & 1.09 & 2.67 & 5.43 & 8.97 & 11.68 & 11.32 & 6.71 & \\
\hline \multicolumn{9}{|c|}{$\operatorname{NAR}\left(\mathrm{g} \mathrm{cm}^{-2}\right.$ day $\left.^{-1}\right) \times 10^{-4}$} \\
\hline $\mathrm{F}_{0}$ & 1.40 & 1.85 & 2.50 & 3.48 & 5.15 & 8.08 & 13.83 & 26.68 \\
\hline$F_{1}$ & 2.38 & 2.00 & 1.80 & 1.60 & 1.45 & 1.10 & 0.38 & -1.48 \\
\hline$F_{2}$ & 2.53 & 2.18 & 1.90 & 1.63 & 1.30 & 0.78 & -0.33 & -2.83 \\
\hline $\mathrm{F}_{3}$ & 2.85 & 2.33 & 2.00 & 1.63 & 1.28 & 0.63 & -0.70 & -3.58 \\
\hline \multicolumn{9}{|c|}{$\operatorname{LAR}\left(\mathrm{cm}^{2} \mathrm{~g}^{-1}\right)$} \\
\hline$F_{0}$ & 427.36 & 324.76 & 234.01 & 158.43 & 100.41 & 59.65 & 33.43 & 17.90 \\
\hline $\mathrm{F}_{1}$ & 343.28 & 335.83 & 305.35 & 257.83 & 202.03 & 146.85 & 98.98 & 61.85 \\
\hline $\mathrm{F}_{2}$ & 334.55 & 323.94 & 293.90 & 249.47 & 197.87 & 146.53 & 101.27 & 65.31 \\
\hline $\mathrm{F}_{3}$ & 312.32 & 309.58 & 286.78 & 247.50 & 198.59 & 148.00 & 102.46 & 65.97 \\
\hline
\end{tabular}


Effect of fertilizer: TDM was higher in all the fertilized plants than in the control plants (Table 2). Increased fertilizer level increased TDM. $F_{3}$ treatment had the highest TDM. Similar trends of the effect of fertilizer were also observed in wheat by Srivastava and Mehrotra (1980), Awasthi and Bhan (1993) and in barley by Hooda and Kalra (1981), Misra et al. (1982), Verma and Singh (1989), Grashoff and D'Antuono (1997), Natr (1997), Sonmez (2000), Alam et al. (2005) and Alam and Haider (2006). Higher LAl was in the fertilizer levels than in the control.The highest LAI was in highest (F3) treatment. Similar results were reported in wheat by Khalifa (1973) and Awasthi and Bhan (1993) and in barley by Hruska and Labounck (1979), Spunarova and Zenisceva (1985), Awasthi and Bhan (1994), Grasshoff and D'Antuono (1997) and Alam and Haider (2006). The increase of LAl was due to the favourable synthesis of growth favouring constituents in plant system due to better supply of fertilizers, which led to the enlargement of leaf area. The depletion of LAl at the later stages was possibly due to the senescence and abscission of the older leaves. Similar result was reported by Boonchoo et al. (1998) in barley. Higher CGR was in the fertilized plants than in the control (Table 2). This result is in agreement with crop like wheat by El-Shaer et al. (1979) and Kumar et al. (1995). LAR declined throughout the whole growing season. Similar result was also noticed in barley by Alam and Haider (2006).

Table 3. Effect of variety on mean values of TDM, LAI, CGR, NAR and LAR at different growth stages.

\begin{tabular}{lcccccccc}
\hline \multicolumn{7}{c}{ Days after sowing } \\
\hline Variety & 20 & 30 & 40 & 50 & 60 & 70 & 80 & 90 \\
\hline TDM (g m-2) & & & & & & & & \\
BARI Barley-1 & 4.19 & 11.57 & 28.79 & 62.85 & 118.80 & 193.48 & 272.00 & 333.53 \\
BARI Barley-2 & 4.19 & 11.63 & 29.06 & 63.61 & 120.39 & 196.03 & 275.16 & 336.49 \\
BHL-3 & 4.32 & 11.87 & 29.35 & 63.77 & 120.22 & 195.73 & 275.72 & 339.43 \\
BL-1 & 4.24 & 11.74 & 29.18 & 63.57 & 119.95 & 195.31 & 275.02 & 338.57 \\
LAI & & & & & & & & \\
BARI Barley-1 & 0.15 & 0.15 & 0.38 & 0.84 & 1.56 & 2.33 & 2.78 & 2.63 \\
BARI Barley-2 & 0.15 & 0.38 & 0.85 & 1.58 & 2.37 & 2.84 & 2.69 & 2.02 \\
BHL-3 & 0.15 & 0.38 & 0.85 & 1.59 & 2.40 & 2.88 & 2.74 & 2.08 \\
BL-1 & 0.15 & 0.38 & 0.84 & 1.56 & 2.36 & 2.82 & 2.68 & 2.02 \\
& $20-30$ & $30-40$ & $40-50$ & $50-60$ & $60-70$ & $70-80$ & $80-90$ & \\
CGR (g m-2 day-1) & & & & & & & & \\
BARI Barley-1 & 0.74 & 1.72 & 3.41 & 5.60 & 7.47 & 7.85 & 6.15 & \\
BARI Barley-2 & 0.75 & 1.74 & 3.46 & 5.68 & 7.57 & 7.91 & 6.13 & \\
BHL-3 & 0.76 & 1.75 & 3.44 & 5.65 & 7.55 & 8.00 & 6.37 & \\
BL-1 & 0.75 & 1.74 & 3.44 & 5.64 & 7.54 & 7.97 & 6.36 & \\
NAR (g cm-2 day-1) & $10-4$ & & & & & & & \\
BARI Barley-1 & 2.25 & 2.08 & 2.05 & 2.08 & 2.33 & 2.65 & 3.28 & 4.53 \\
BARI Barley-2 & 2.28 & 2.10 & 2.05 & 2.10 & 2.30 & 2.63 & 3.25 & 4.53 \\
BHL-3 & 2.30 & 2.08 & 2.05 & 2.05 & 2.25 & 2.60 & 3.23 & 4.63 \\
BL-1 & 2.33 & 2.10 & 2.05 & 2.10 & 2.30 & 2.70 & 3.43 & 5.13 \\
LAR (cm g $^{-1}$ ) & & & & & & & & \\
BARI Barley-1 & 358.03 & 325.31 & 280.35 & 227.71 & 173.67 & 124.12 & 83.03 & 51.94 \\
BARI Barley-2 & 356.96 & 324.55 & 280.01 & 227.82 & 174.18 & 124.86 & 83.84 & 52.72 \\
BHL-3 & 347.73 & 321.57 & 281.01 & 230.81 & 177.50 & 127.62 & 85.70 & 53.74 \\
BL-1 & 354.80 & 322.68 & 278.61 & 226.87 & 173.55 & 124.45 & 83.58 & 52.54 \\
\hline
\end{tabular}

Effect of variety: Among the varieties, BHL-3 produced the highest TDM (Table 3). The lowest TDM was in BARI Barley-2. The highest LAI was in BHL-3 and the lowest LAI was similar in the remaining three varieties. The highest CGR was also in BHL-3 and BARI Barley-1 had the lowest CGR. The highest NAR was in BL-1 and the lowest was in the other varieties. Irrigated and NPK fertilized crops gave better performance than the rain fed crops. The highest TDM, LAI and CGR were being observed at $I_{2}$ irrigation $(40 \mathrm{~mm})$ and $F_{3}$ fertilizer level $(120,100,60)$. Higher growth and growth attributes were in BHL-3 than the other varieties. 


\section{References}

Alam M Z and Haider S A (2006) Growth attributes of barley (Hordeum vulgare L.) cultivars in relation to different doses of nitrogen fertilizer. J. Life Earth Sci. 1: 77-82.

Alam M Z, Haider S A and Paul N K (2005) Effects of sowing time and nitrogen fertilizer on barley (Hordeum vulgare L.). Bangladesh J. Bot. 34: 27-30.

Awasthi U D and Bhan S (1993) Performance of wheat (Triticum aestivum) varieties with different levels of nitrogen in moisture-scarce condition. Indian J. Agron. 38:200-203.

Awasthi U D and Bhan S (1994) Physiological response of barley genotypes to nitrogen levels under moisture scarce conditions on light textured soils of ventral Uttar Pradesh. Indian J. Plant Physiol. 37:32-34.

Boonchoo S, Fukai S and Suzan Hetherington E (1998) Barley yield grain protein concentration as affected by assimilate and nitrogen availability. Aust. J. Agric. Res. 49:695-706.

El-Shaer M H, Abo Al-Zahab A A, El-Hattab A H and Hassan A A (1979) Effect of nitrogen on growth analysis, yield and yield contributing variables in three Egyptian cotton cultivars (Gossypium barbadense L.). J. Agron. Crop Sci. 148:249-262.

FAO (2002) FAOSTAT: Statistics database (Online). (Subset Production within Agriculture database) Available at $h$ ttp: 11 apps. fao.org

Gomez K A and Gomez A A (1984) Statistical Procedure for Agricultural Research. John Wiley and Sons. New York.

Grasshoff C and D'Antuono L F (1997) Effect of shading and nitrogen application on yield, grain size distribution and concentrations of nitrogen and water soluble carbohydtrates in malting spring barley (Hordeum vulgare L.). Euopean J. Agron. 6:275-293.

Hooda R S and Kalra G S (1981) Effect of nitrogen on dry matter production and uptake of nitrogen by barley under irrigated and rainfed conditions. Agric. Sci. Digest. 1:149-151.

Hruska L and Labounck V (1979) The reaction of different types of spring barley cultivars to cultural practices. Rostlinna Vyroba. 25:933-943.

Khalifa M A (1973) Effects of nitrogen on leaf area index, leaf area duration and net assimilation rate and yield of wheat. Agron. J. 65:253-256.

Kirby E J M (1969) The growth and development of some barley varieties in response to irrigation and nitrogen fertilizer. J. agric. Sci., Camb. 72:467-474.

Kumar A, Sharma D K and Sharma H C (1995) Response of wheat (Triticum aestivum) to irrigation and nitrogen in sodic soils. Indian J. Agron. 40:38-42.

Misra B N, Verma B S and Singh K N (1982) N, P and K requirements of two-row barley. Indian J. agric. Sci. 52:669-673.

Nahar N and Paul N K (1998) Growth analysis of wheat genotypes under differing soil moisture regimes. Bangladesh J. Agri. 23:57-64.

Natr L (1997) The effect of nitrogen on dry matter allocation in young spring barley plants ( Hordeum vulgare L.). Scientia Agriculrurae Bohemica 28:7-16.

Rahman M S, Sarker A M, Islam M S and Paul N K (2001) Effect of soil moisture on grain yield of wheat (Triticum aestivum L.) cultivars. Environ. Ecol.19:304-308.

Saha S K and Paul N K (1995) Growth of five wheat (Triticum aestivum L.) cultivars as affected by soil moisture. J. biosci.. 3:103-112. 
Sarker A M and Paul N K (1997) Effect of soil moisture on growth, yield and quality of wheat. Rajshahi Univ. Stud. 25: 247-256.

Sarker A M and Paul N K (1998) Studies on the growth attributes of wheat under irrigated and rainfed conditions. Bangladesh J. Bot. 27:119-126.

Sarker A M, Paul N K and Bari M A (1996) Effect of soil moisture on shoot and root growth of wheat (Triticum aestivum L.). J. bio-sci.. 4:63-69.

Siddique M R B, Hamid A and Islam M S (1999) Drought stress effect on the phenological characters of wheat. Bangladesh J. Agril. Res. 24:255-263.

Simane B, Peacock J M and Struik P C (1993) Differences in developmental plasticity and growth rate among drought resistant and susceptible cultivars of durum wheat (Triticum aestivum L. var. durum). Plant and Soil 157:155-1666.

Sonmez F (2000) Effect of seed size and nitrogen fertilizer on root and shoot growth in the early development stage of barley. Turkish J. Agric. Forest 24:669-675.

Spunarova M and Zenisceva L (1985) The effect of nitrogen and soil moisture on leaf area index, productivity and yield of spring barley. Rostlina Vyroba 31:417-424.

Srivastava R D L and Mehrotra O N (1980) Effect of rate and method of nitrogen application on its uptake, dry matter production and their partitioning in dwarf wheat. Indian J. Plant Physiool. 23:148-155.

Talukder M S U (1987) Growth and development of wheat as affected by soil moisture stress. Indian J. agric. Sci. 57: $559-564$.

Thorne G N (1960) Variation with age in net assimilation rate and other growth attributes of sugar beet, potato and barley in a controlled environment. Ann. Bot 24: 256-272.

Verma R S and Singh R R (1989) Dry matter accumulation pattern of malt-barleys (Hordeum distichum L.) as influenced by seeding rates and nitrogen fertilization. Indian J. Agril. Res. 24:109-116. 